\title{
Format Rancangan Sistem Informasi Manajemen Masjid
}

\author{
Mochammaad Dimas Nauval \\ Telkom University \\ Email:mdimasnauval@telkomuniversity.ac.id
}

\begin{abstract}
.Sistem Informasi mengenai kegiatan kepada para jamaah khususnya \& masyarakat pada umumnya merupakan suatu system yang berfungsi untuk mempermudah pengetahuan informasi mengenai rumah ibadah sekitar. Masyarakat dapat mengetahui seluruh kegiatan dari rumah ibadah melalui gadget
\end{abstract}

Keywords: rumah ibada, sistem, informasi

Paper ini akan dipublikasikan di osf.io [a] menggunakan format standard perancangan sistem informasi [b]

\section{Introduction}

1.1. Business case

Definisi Proyek: Sistem informasi manajemen masjid dengan menggunakan Bahasa pemograman. Tujuan proyek: mempermudah masyarakat untuk menerima informasi dari kegiatan di masjid sekitar. Definisi system: system akan di input oleh admin, masyarakat dapat mengakses website menggunakan gadget.

\subsection{System Requirement}

System Function: Explains the specific and detailed system function. System Feature: Explains the specific and detailed system features. Acceptance Criteria: Explains the specific and detailed system acceptance criteria System user level: Explains the specific and detailed user level that will using the system

Fungsi system: Memberi akses kepada masyarakat untuk informasi di masjid. Fitur system: melihat jadwal khutbah, kegiatan, berita, zakat, dan qurban. Kriteria yang diterima: pada umumnya masyarakat sulit untuk mengetahui kegiatan apa saja yang ada dimasjid. Jadi system akan di akses melalui gadget untuk mempermudah mengambil informasi kegiatan masjid. Tingkatan Pengguna pada Sistem: Admin, Takmir, Jamaah.

Click or tap here to enter text.

\section{Penjelasan SIngkat Terkait Metode}

Adapun penjelasan mengenai fase metodologi pengembangan system ini adalah sebagai berikut: a) perencanaan: meliputi penjadwalan perancangan system; b) analisis: membuat analisis aliran kerja manajemen yang sedang berjalan; c) Implementasi: menerapkan rancangan dari tahap-tahap sebelumnya dan melakukan uji coba; d) Perawatan: dilakukan untuk menjaga system tetap mampu beroperasi 
Sistem dirancang untuk memenuhi kebutuhan pengunjung atau jamaah dalam memperoleh informasi dari masjid dengan menggunakan Bahasa pemograman yang nantinya dapat diakses oleh jamaah melalui gadget

Click or tap here to enter text.

3.2. Data Flow Diagram (DFD)

Data Flow Diagram adalah suatu diagram yang menggunakan notasi-notasi untuk menggambarkan arus dari data system, yang penggunaannya sangat membantu untuk memahami secara logika, terstruktur dan jelas (Azzolini, 2013).

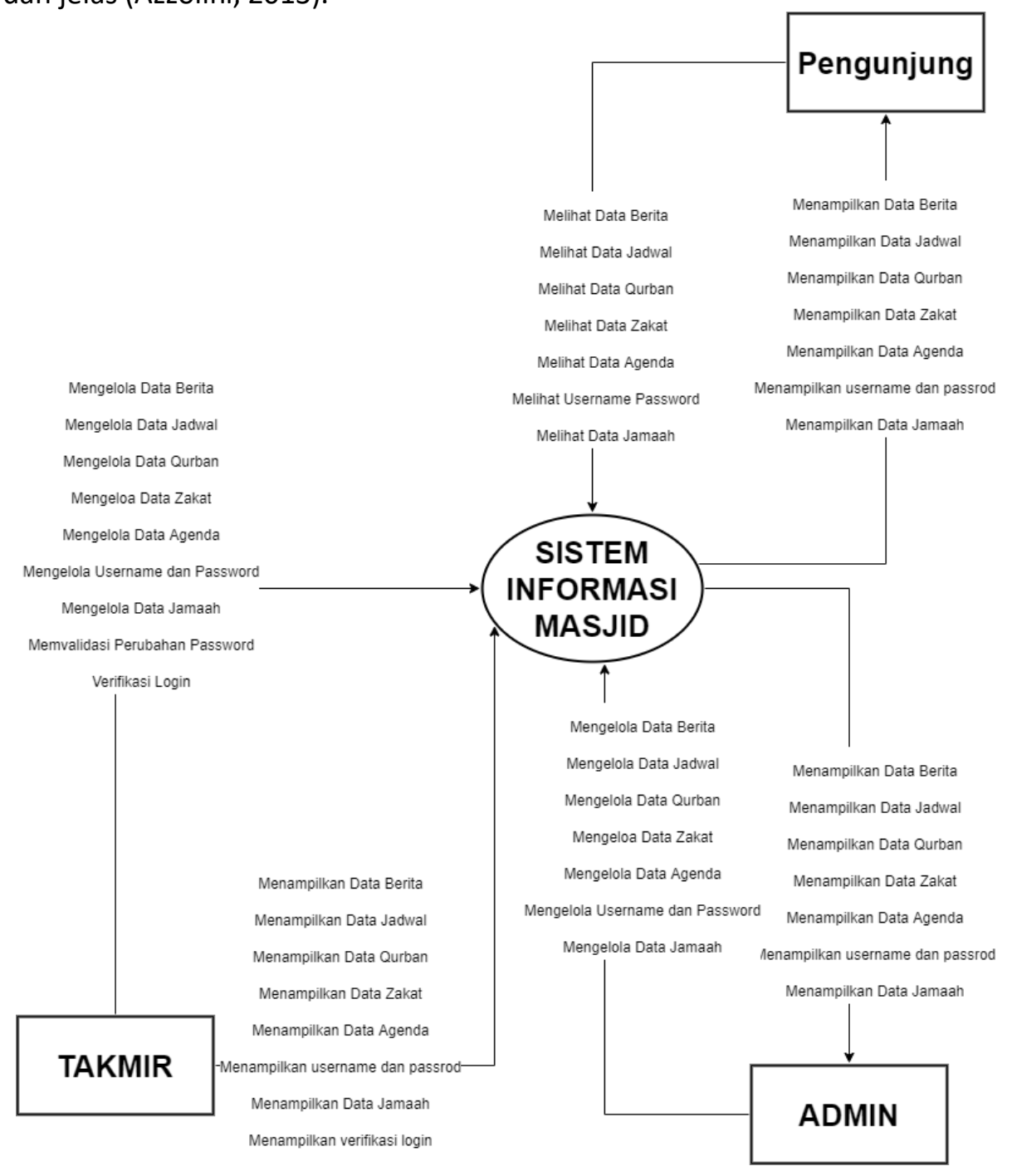




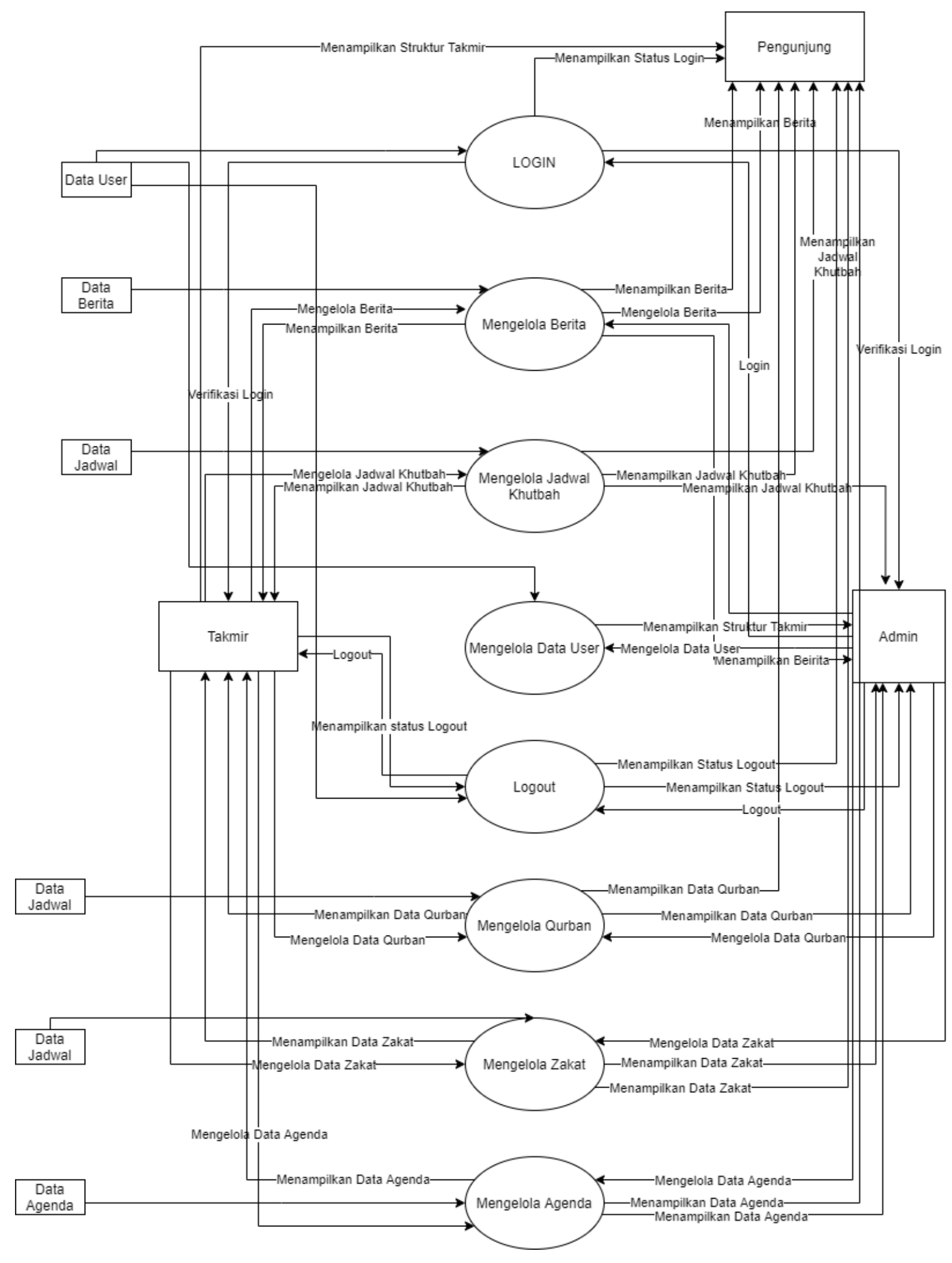




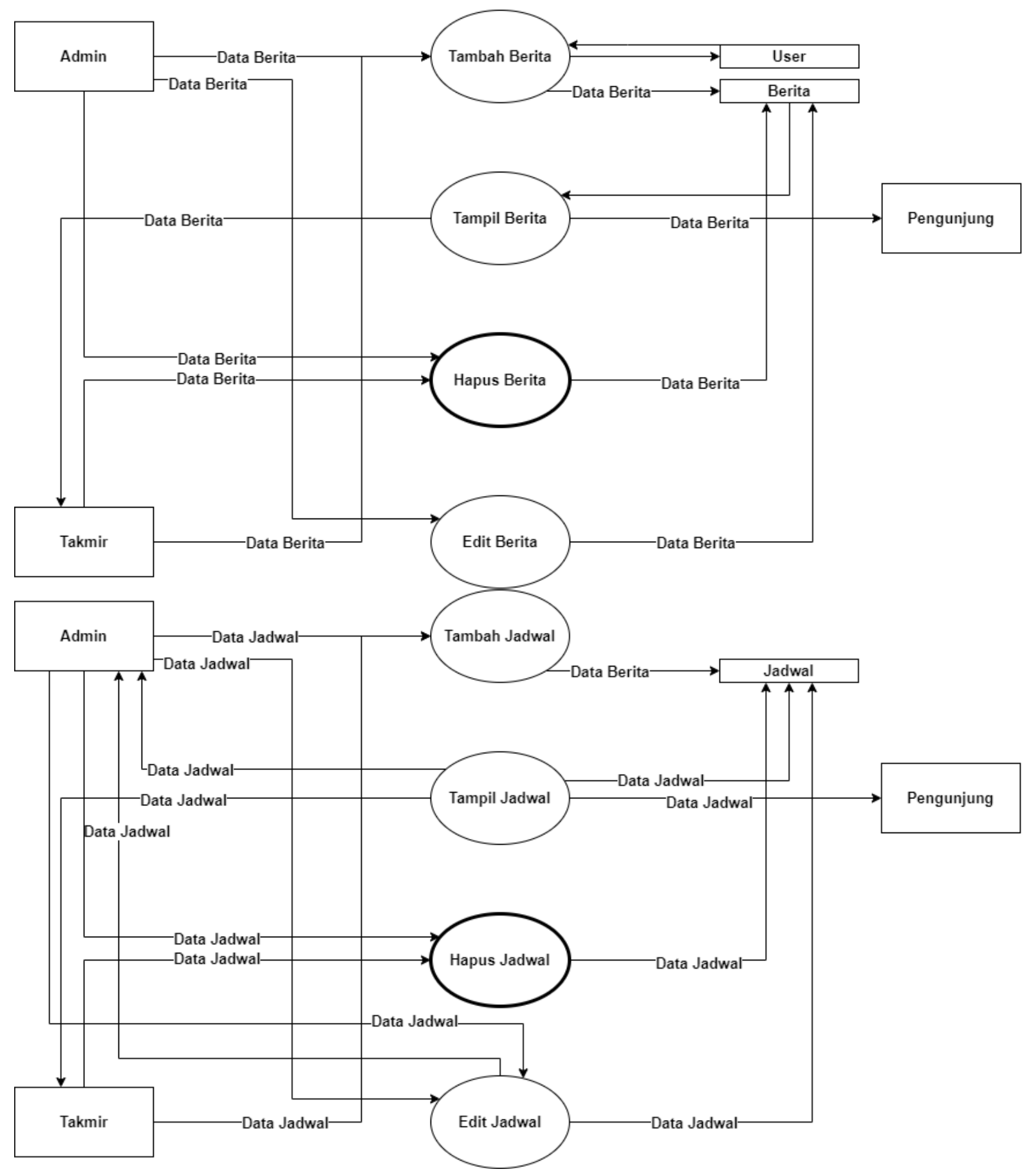




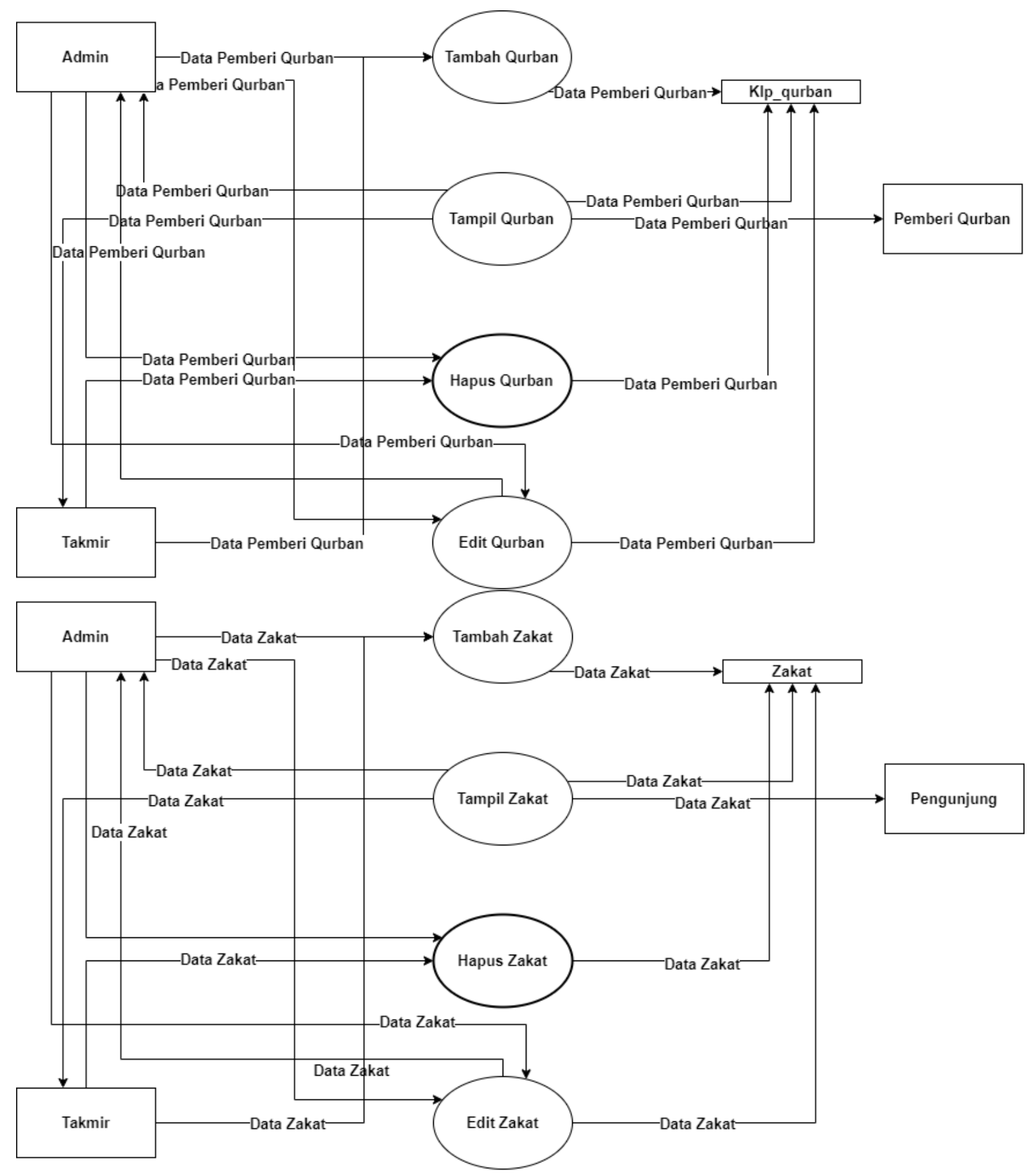

Figure 1 Gambar Data Flow Diagram

3.3. Entity Relationship Diagram (ERD)

ERD (Entity Relationship Diagram) adalah model konseptual yang mendeskripsikan hubungan penyimpanan (dalam DFD). Karena itu, ERD berbeda dengan DFD (DFD memodelkan fungsi system), atau dengan STD (State Transition Diagram), yaitu memodelkan system dari segi ketergantungan terhadap waktu. ERD digunakan untuk memodelkan struktur data dan hubungan dalam data, karena hal ini relative kompleks. (Pohan \& Bahri, 1997). 


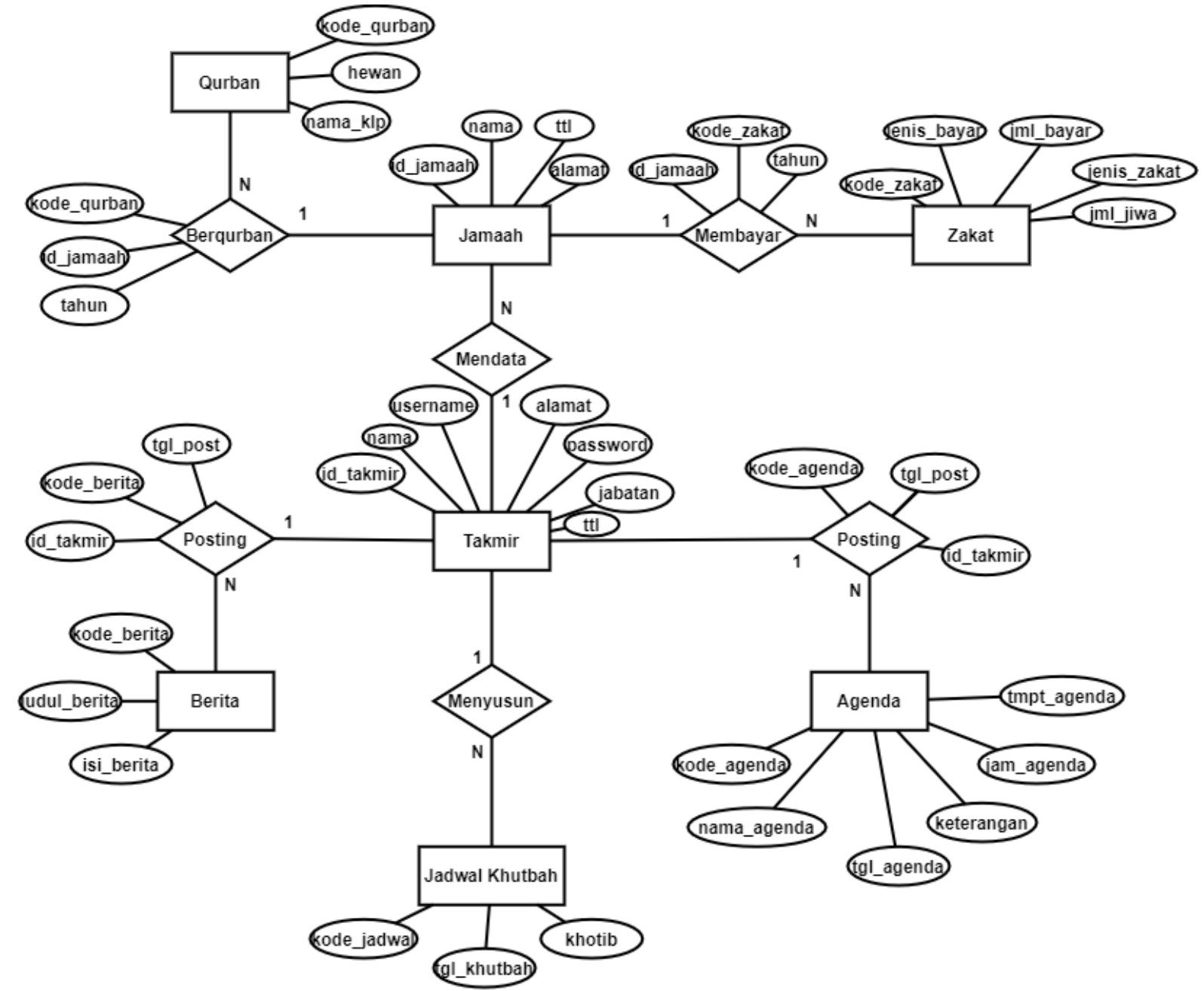

Figure 4 Gambar ERD

\subsection{Database Design}

Database memiliki nama datauser dimana menampung user dalam himpunan dan rolenya masingmasing.

3.5 Use Case Diagram

Pada usecase diagram menunjukan superadmin berhak atas semua fungsi diantaranya fungsi login, manajemen berita/kegiatan. 


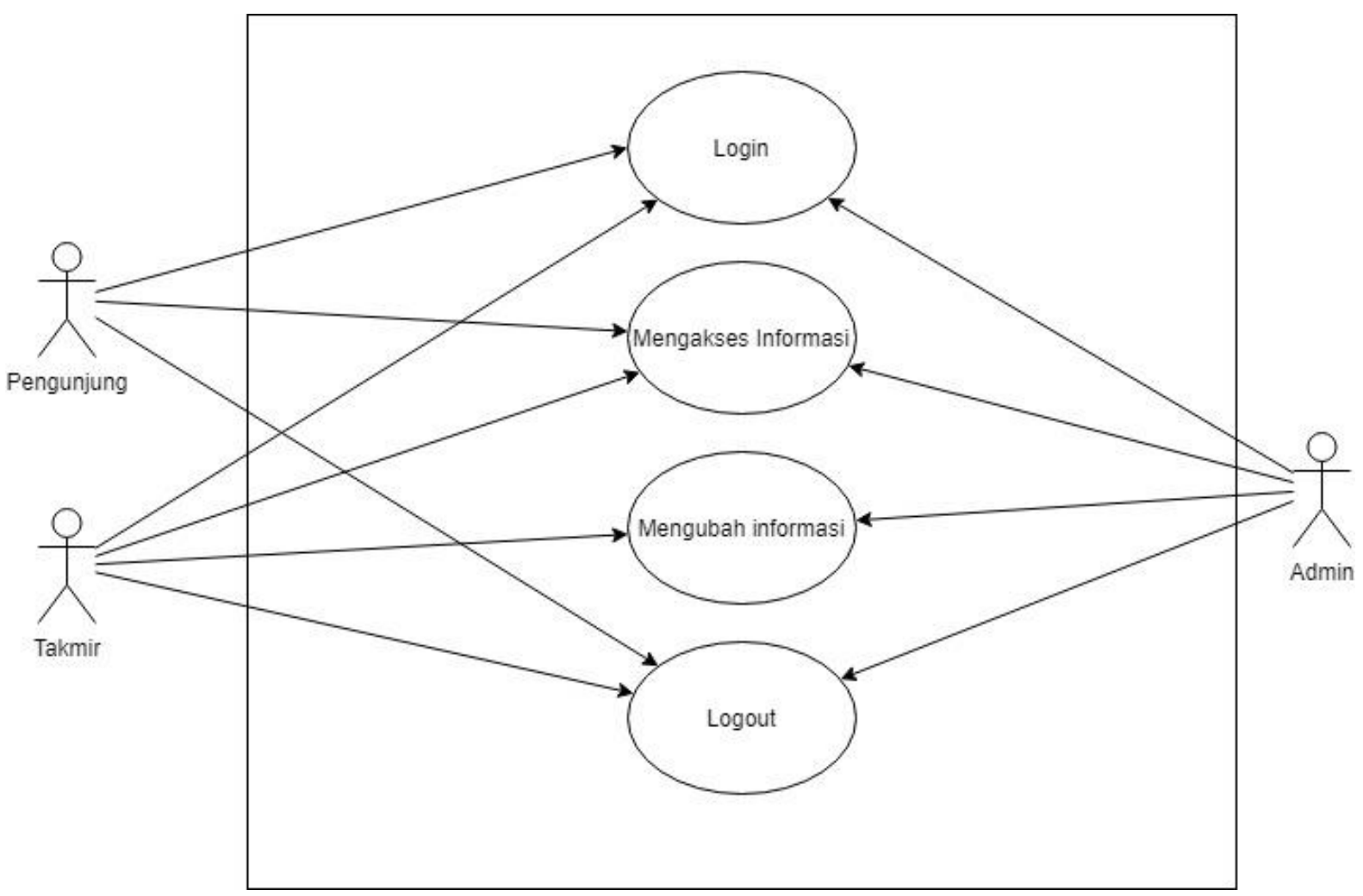

Figure 5 Gambar Use Case Diagram

\subsection{Activity Diagram}

Activity diagram menunjukkan aktivitas admin dari memasukan data kegiatan ke dalam system sampai data tersebut dapat dilihat oleh pengguna. Aktivitas tersebut dimulai dari admin login ke system setelah itu admin menambahkan data kegiatan kedalam system, sampai data dapat dilihat oleh pengguna. 


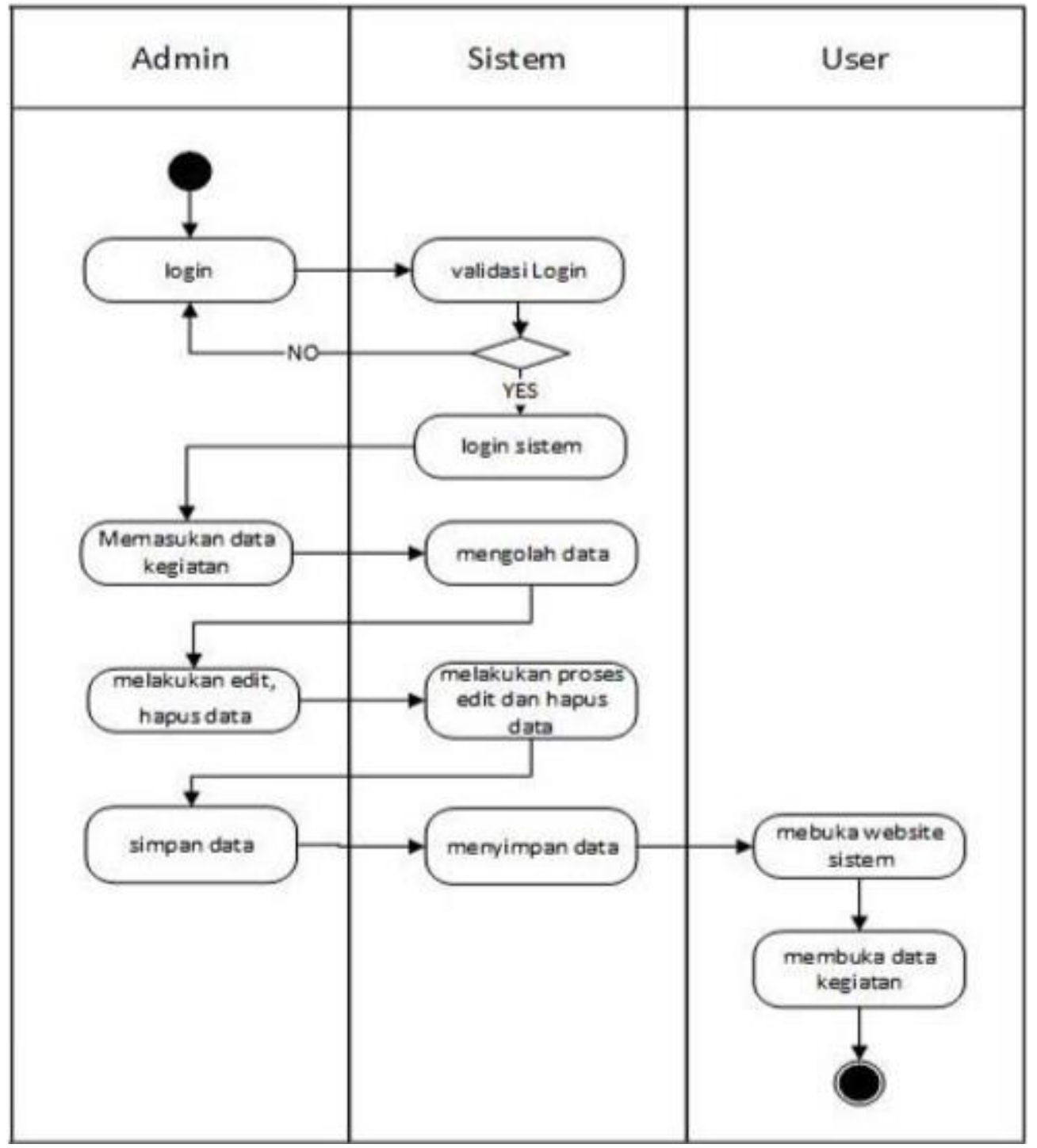

Figure 6 Gambar Activity Diagram

3.7 Sequence Diagram

Proses dilakukan admin, proses dilakukan oleh admin memilih data yang akan ditambah, menambah data kegiatan, tambah data, sampai pesan data kegiatan sudah ditambahkan 


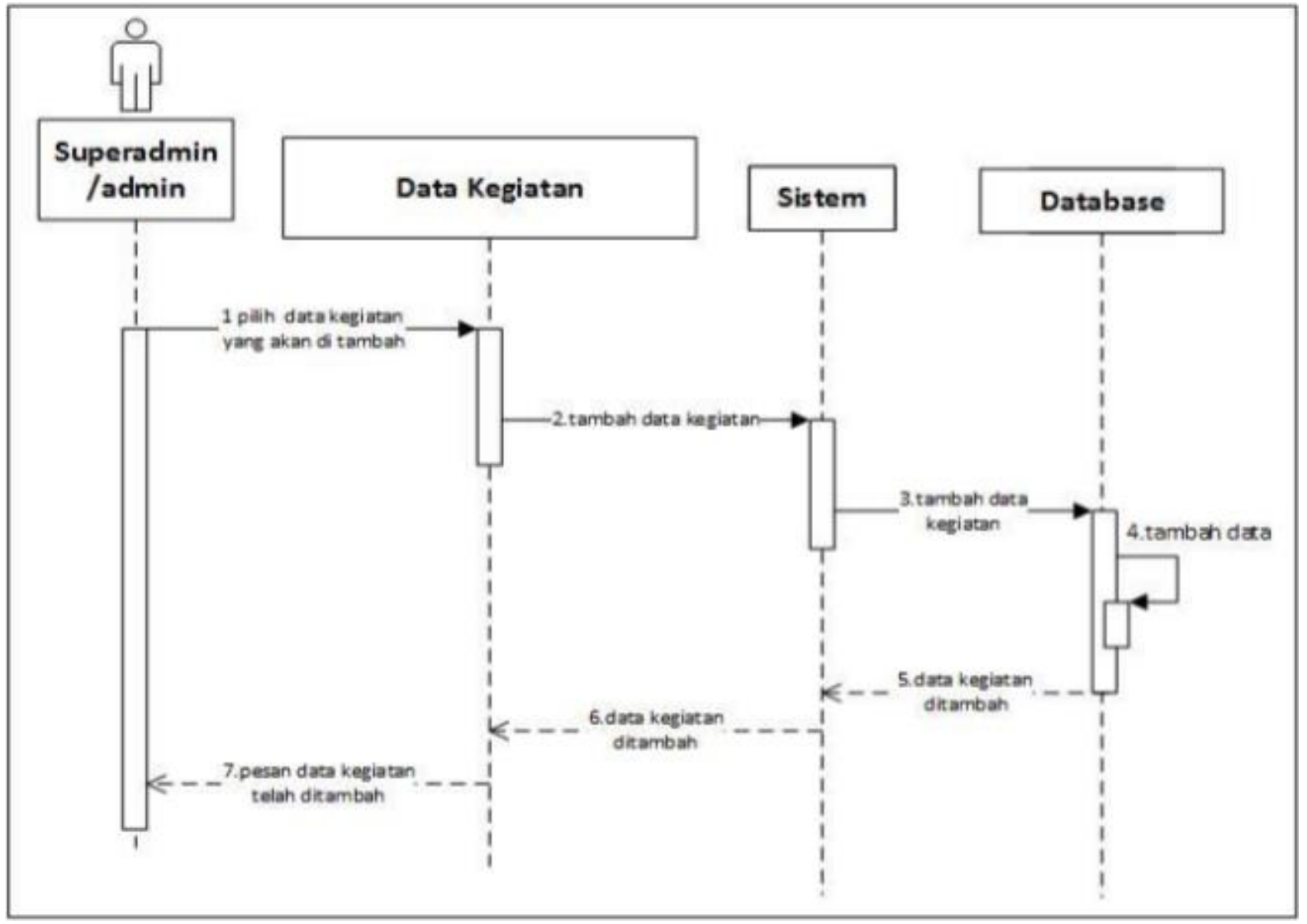

Figure 7 Gambar

3.8 Interface Design

Click or tap here to enter text.

氮 Query Agenda

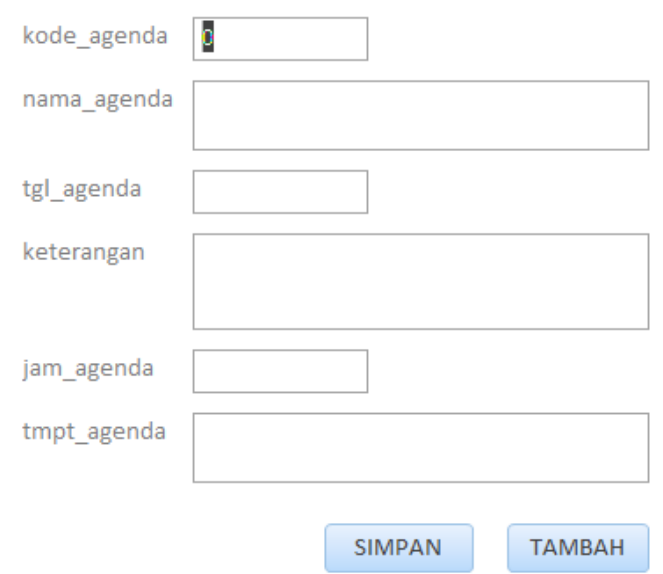




\section{-日aery Jadwal Khutbah}

kode_jadwal

tgl_khutbah

khotib

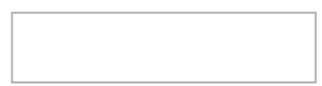

SIMPAN

TAMBAH

F Agenda

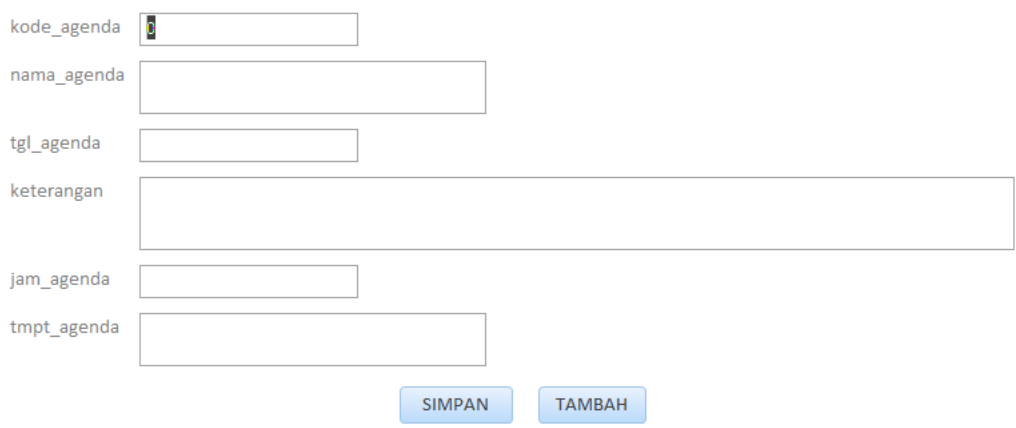

F Agenda

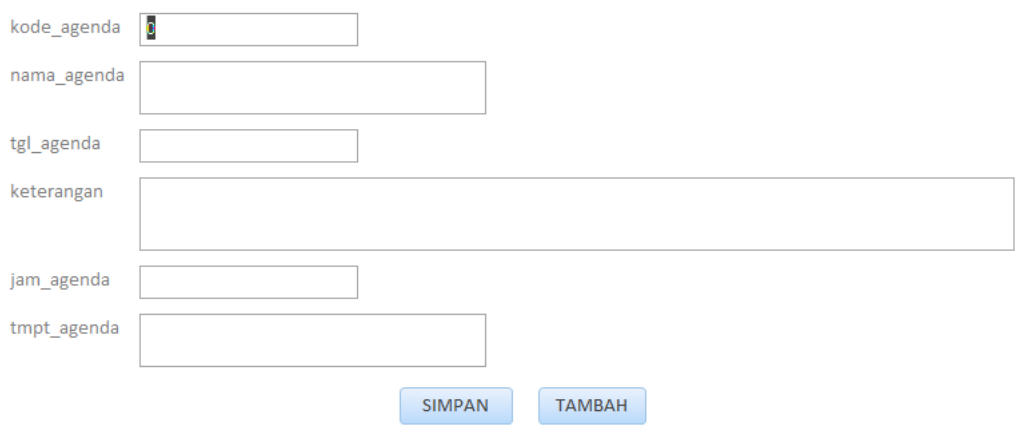

Query Jamaah

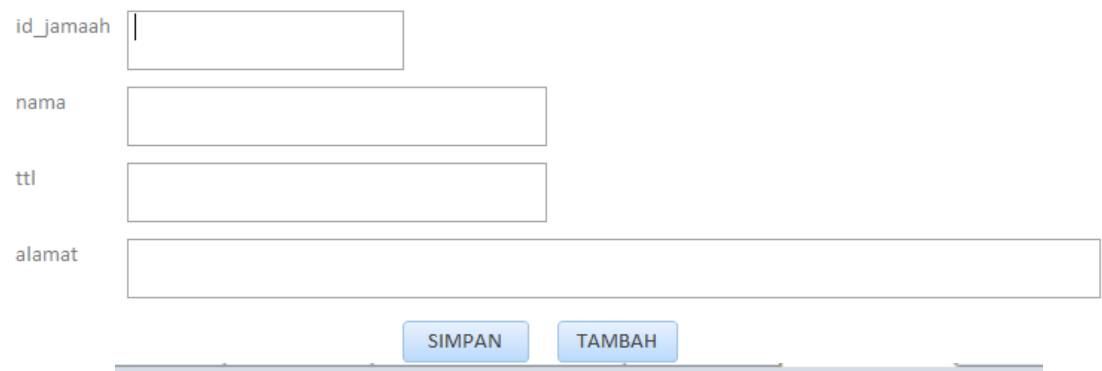

\section{登 Query Qurban}

\section{kode_qurban}

hewan

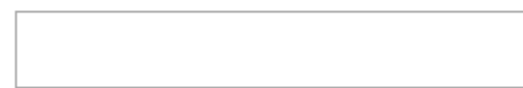

nama_klp

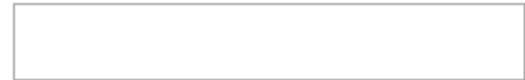



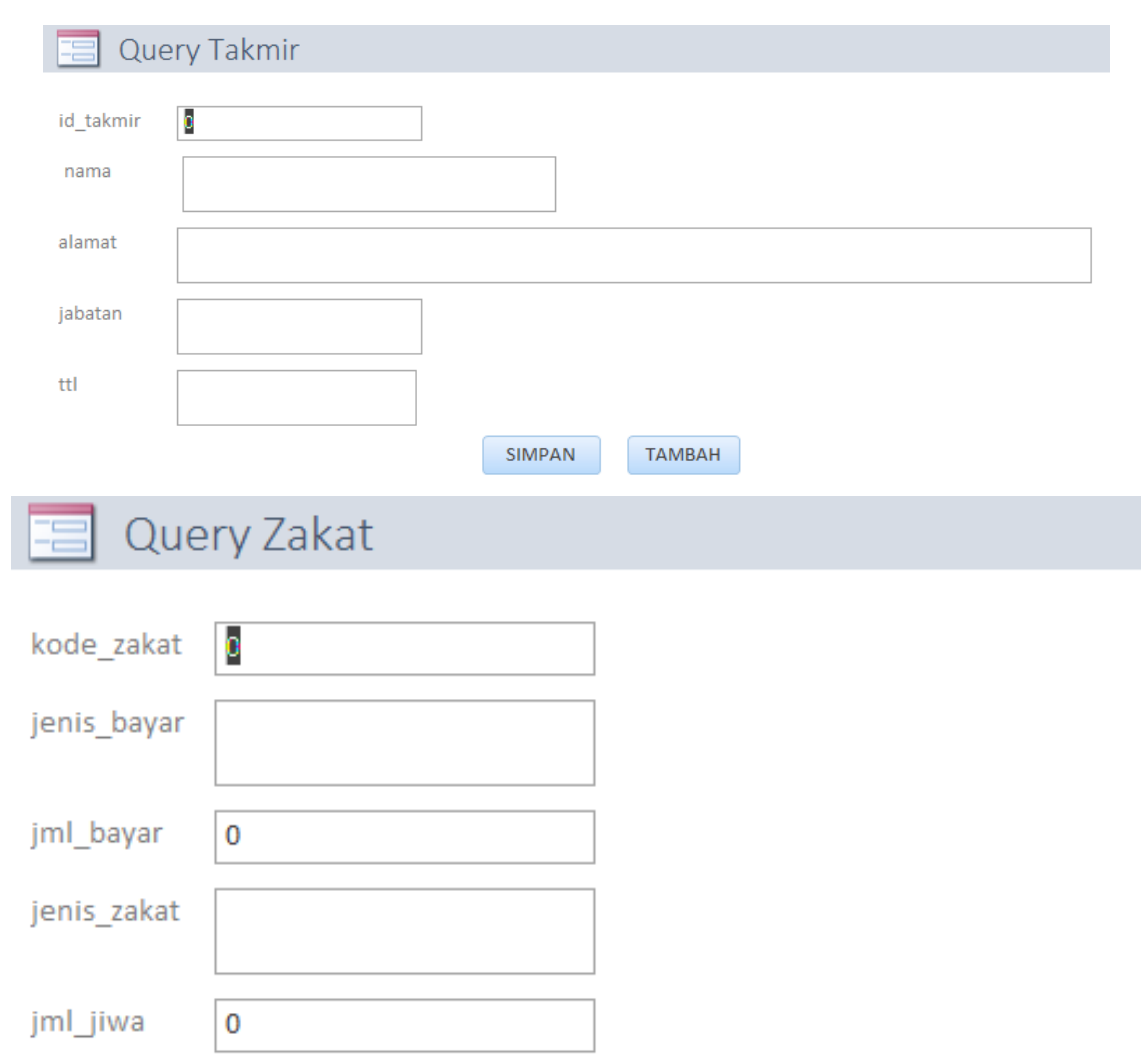

\begin{tabular}{ll} 
SIMPAN TAMBAH & TAN \\
\hline
\end{tabular}

Figure 8 Gambar

3.9 Source Code

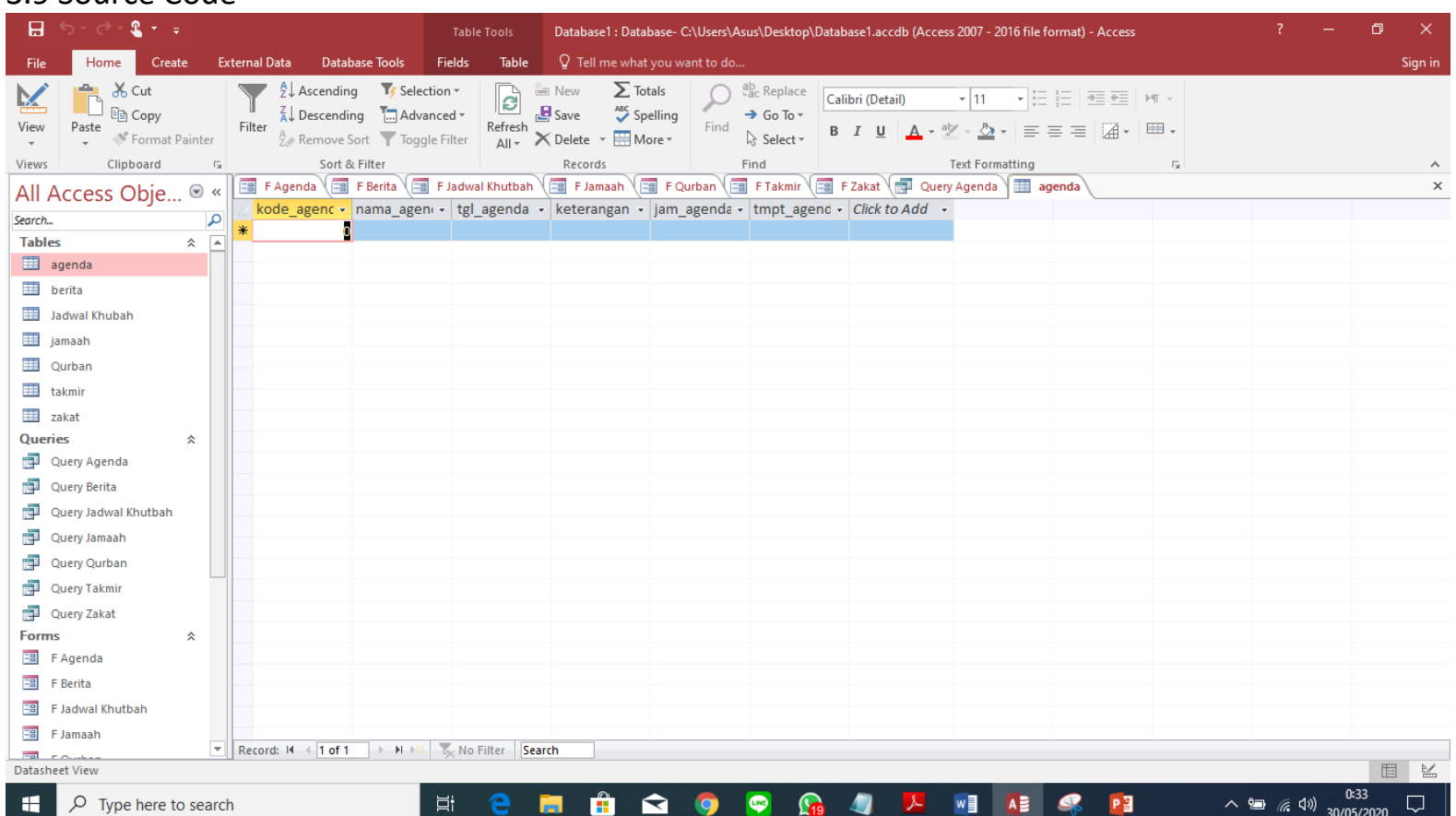

4 Penutup

4.1 Kesimpulan 
Melalui pembahasan yang telah diuraikan pada bab sebelumnya, maka dapat ditarik beberapa kesimpulan, yaitu: a) Dengan adanya Sistem Informasi Manajemen Masjid pengelolaan data lebih efisien; b) Sistem Informasi berbasis web memudahkan dalam penyimpan data dan memudahkan dalam memberikan informasi kepada jamaah.

\subsection{Saran}

Saran yang dapat penulis sampaikan untuk pengembangan system ini selanjutnya adalah penunjukan staff khusus untuk melakukan pengawasan terhadap konten website dan adanya perpanjangan website sebelum masa aktif berakhir.

\section{References}

[1] Wardana T.L., \& Aribowo, E. (2013). Perancangan Dan Implementasi Sistem Inforamsi Manajemen Kegiatan Masjid Studi Kasus: Masjid Jogokariyan Yogyakarta. Jurnal Sarjana Teknik Informatika, 1(1), 119-128.

\section{Additional}

[a] R. Aurachman, "Review Terhadap OSF.IO Sebagai Sarana Publikasi Preprint," OSF Preprints, 17 May 2020. doi:10.31219/osf.io/rvumx , Available: https://osf.io rvumx

[b] R. Aurachman, "Kerangka Perancangan Sistem Informasi Sebagai Pembelajaran Mahasiswa Teknik Industri," osf.io, doi:10.31219/osf.io/tmpcn , 5 2020. Available: https://osf.io/tmpen 